\title{
The Efficacy and Safety of Topical $\beta$-Blockers in Treating Infantile Hemangiomas: A Meta-Analysis Including 11 Randomized Controlled Trials
}

\author{
Xinhui Wang ${ }^{a}$ Wei Feng $^{a}$ Xufeng Zhao ${ }^{a}$ Ziyu Liu $^{a}$ Liang Dong $^{b}$ \\ a Graduate School, Tianjin Medical University, Tianjin, China; 'b Department of Pediatric Surgery, Tianjin Children's \\ Hospital, Tianjin, China
}

\section{Keywords}

Infantile hemangiomas · Topical $\beta$-blockers · Timolol ·

Propranolol $\cdot$ Meta-analysis $\cdot$ Randomized controlled trials

\begin{abstract}
Background: To evaluate the efficacy and safety of topical $\beta$-blockers in the treatment of superficial infantile hemangiomas $(\mathrm{SIH})$ and mixed infantile hemangiomas $(\mathrm{MIH})$, respectively, and compare the efficacy and safety of topical $\beta$-blockers with other interventions. Methods: The PRISMA guidelines were adhered to. We searched for randomized controlled trials in databases from 2010 to 2018 comparing topical $\beta$-blockers with other interventions for infantile hemangiomas. The outcomes evaluated were efficacy and adverse effects. Data analyses were performed using RevMan 5.3. Publication bias was assessed to account for bias in patient selection. Results: Eleven studies, involving 1,235 patients, were subjected to this meta-analysis. Six studies compared topical $\beta$-blockers with other interventions (propranolol, placebo, corticosteroids or pulsed dye laser) in treating $\mathrm{SIH}$, and 5 studies evaluated the efficacy and safety of a topical $\beta$-blocker when it was combined with another intervention in treating $\mathrm{MIH}$. A topical $\beta$-blocker was discovered to be as effective as oral propranolol in treating $\mathrm{SIH}$ (risk ratio, $\mathrm{RR}, 0.96,95 \%$ confidence interval, $\mathrm{Cl}, 0.91-1.02, p=0.20, \mathrm{I}^{2}=$ $0 \%)$, and topical $\beta$-blockers were more beneficial than pla-
\end{abstract}

karger@karger.com www.karger.com/drm

Karger $\stackrel{\text { ' }}{5}$

GOPEN ACCESS
(C) 2020 The Author(s)

Published by S. Karger AG, Basel

This is an Open Access article licensed under the Creative Commons Attribution-NonCommercial-4.0 International License (CC BY-NC) (http://www.karger.com/Services/OpenAccessLicense), applicable to the online version of the article only. Usage and distribution for commercial purposes requires written permission. cebo, corticosteroids or pulsed dye laser in treating SIH (RR $2.25,95 \% \mathrm{Cl} 1.66-3.05, p<0.00001, R^{2}=0 \%$ ). Topical $\beta$-blockers combined with another intervention gave rise to a better clinical response in the treatment of $\mathrm{MIH}$ than intervention alone ( $\mathrm{RR} 1.99,95 \% \mathrm{Cl} 1.10-3.60, p=0.02,1^{2}=55 \%$ ) (standard mean difference $0.80,95 \% \mathrm{Cl} 0.28-1.31, p=0.002$, $R^{2}=0 \%$ ). Compared with oral propranolol, topical $\beta$-blockers were associated with fewer incidences of adverse effects (RR $\left.0.05,95 \% \mathrm{Cl} 0.01-0.39, p=0.004, I^{2}=0 \%\right)$. No significant difference in adverse effects was found when a topical $\beta$-blocker was combined with another intervention in treating MIH (RR $\left.1.01,95 \% \mathrm{Cl} 0.58-1.74, p=0.98, I^{2}=0 \%\right)$. Conclusions: This meta-analysis provided evidence that topical $\beta$-blockers may replace oral propranolol as first-line therapy for SIH and that they are of additive value in treating $\mathrm{MIH}$.

(c) 2020 The Author(s)

Published by S. Karger AG, Basel

\section{Introduction}

Hemangioma is a true hemangioma with vascular endothelial cell proliferation, which is a common and frequent disease in children. The incidence rate is up to $4-10 \%$ in infants, and $22.9 \%$ in preterm infants with ultra-low birth weight, i.e. $<1,000 \mathrm{~g}$ [1]. At present, the pathogenesis of hemangioma is still not completely clear, and the following 3 theories have been highly discussed: 
Fig. 1. Flowchart of the Materials and Methods. RCT, randomized controlled trial.

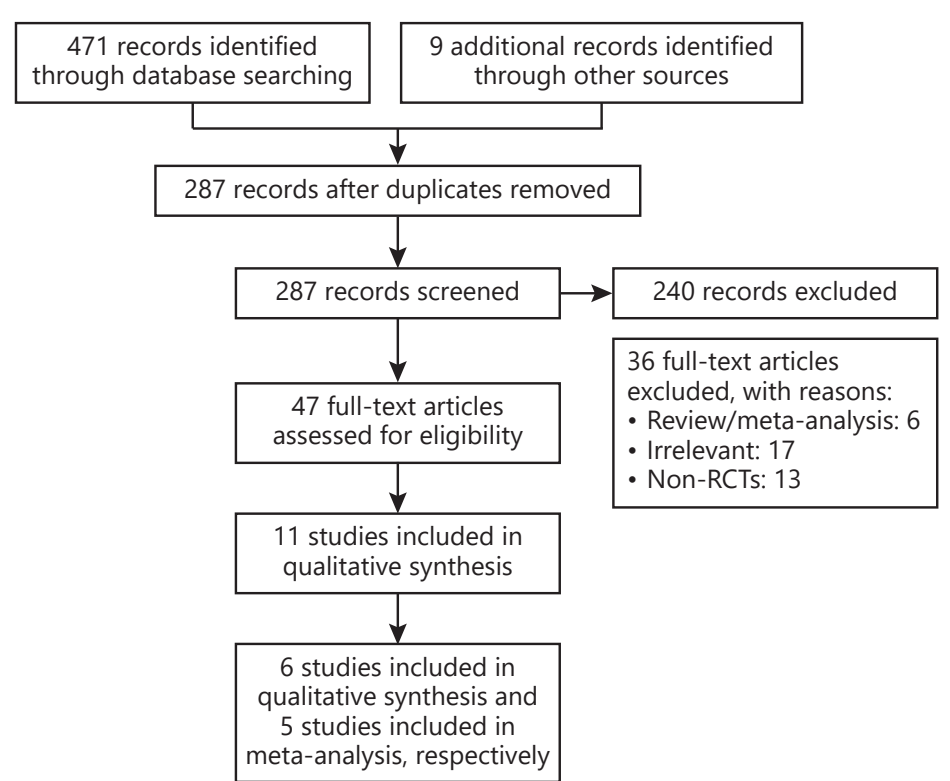

the embryonal vascular dysplasia and embryonal residue theory, the estrogen theory and angiogenic disease [2]. Infantile hemangioma ( $\mathrm{IH}$ ) may be classified according to their depth: superficial, located in the upper dermis (and therefore visible on the skin), deep, extending to subcutaneous fascia or mixed [3]. Most hemangiomas do not require treatment except in the following situations: particularly large to affect areas where resolution may be incomplete such as around the nose, lips or ears, ulcerating or interfering with important functions of the senses, such as feeding, breathing, hearing or vision [4].

Multiple studies have confirmed the therapeutic role of $\beta$-blockers such as propranolol in IH since the report of Léauté-Labrèze et al. [5]. However, systemic adverse effects of oral propranolol are well known, including bronchospasm, hypotension, bradycardia, congestive heart failure and hypoglycemia [6]. Infants treated with oral propranolol must be closely monitored, so theoretically topical $\beta$-blockers might be a safe and effective alternative in $\mathrm{IH}$.

Guo and Ni [7] described firstly the topical management for capillary hemangioma of the eyelid using the $\beta$-blocker solution in patients with superficial lesions, and they demonstrated that the application of topical $\beta$-blockers produced an obvious reduction of a large capillary hemangioma. This article conducted a meta-analysis of all randomized controlled trials on topical $\beta$-blockers since 2010, aiming to evaluate the efficacy and safety of topical $\beta$-blockers in the treatment of superficial infantile hemangiomas (SIH) and mixed infantile hemangiomas $(\mathrm{MIH})$, respectively, and provide an evidence-based reference value for more studies in the future.

\section{Material and Methods}

For further details, see the online supplementary material (see www.karger.com/doi/10.1159/000510029) (Fig. 1).

\section{Results}

\section{Eligible Studies}

Eleven studies enrolling 1,235 infants with hemangiomas that met our inclusion criteria were included in our meta-analysis. Six [8-13] of 11 studies compared the efficacy and safety of a single topical $\beta$-blocker with other interventions (such as oral propranolol, placebo, corticosteroids, laser or radiation) in the treatment of SIH, and 5 [14-18] of 11 studies evaluated the efficacy and safety of a topical $\beta$-blocker when it was combined with another intervention in treating MIH. A flow diagram that illustrates the search process is shown in Figure 1. Regarding the methodological quality of trials, each randomized controlled trial is shown in Figure 2. All the included studies presented moderate and high quality with the acceptable risk of bias. 


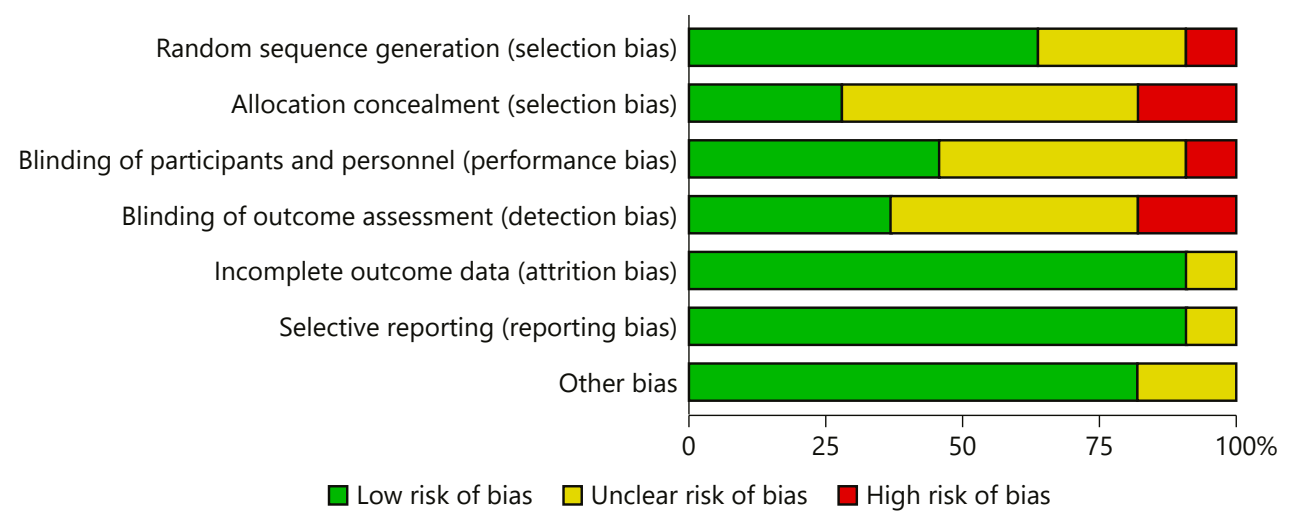

Fig. 2. Risk of bias graph.

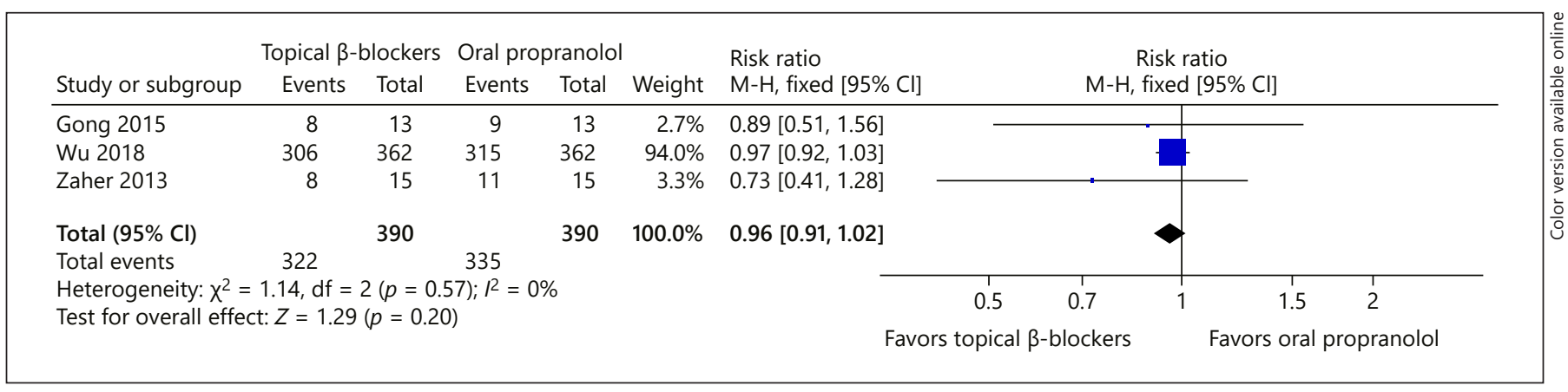

Fig. 3. Forest plot of the efficacy of topical $\beta$-blockers compared with oral propranolol in treating SIH.

\section{Patient Characteristics}

The age at treatment initiation ranged from 2 to 6.1 months, and treatment duration ranged from 3 to 10 months. In our meta-analysis, 2 types of topical $\beta$-blockers were included (timolol maleate and propranolol). Two topical timolol maleate formulations (gel and solution) were used, and timolol maleate concentrations were $0.5 \%$. One percent topical propranolol ointment was used twice daily. The lesions were located all over the body, including the head, neck, torso, extremities and the anogenital region. All studies used clinicians to evaluate the treatment response. Three $[8,14,15]$ studies used a visual analog scale to evaluate the therapeutic efficacy in appearance, color and size, and 1 study [11] used clinical photography to document the change in volume. The Achauer grading system was used in 7 studies to assess the reduction in lesion size as poor (0-25\%), fair (26-50\%), good (51-75\%) or excellent (76-100\%). A good or excellent response was considered an effective treatment [19].
The characteristics of the included studies are shown in Tables 1 and 2.

\section{Results from the Meta-Analysis}

Outcomes of Efficacy

Topical $\beta$-Blockers versus Oral Propranolol in Treating $S I H$. Three studies with $780 \mathrm{SIH}$ patients compared the efficacy of topical $\beta$-blockers with oral propranolol in treating SIH. In our meta-analysis, the difference in the efficacy was not significant between 2 groups (risk ratio, $\mathrm{RR}, 0.96,95 \%$ confidence interval, CI, 0.91-1.02, $p=$ $0.20)$. There was no heterogeneity, and the fixed-effect model was used for analysis $\left(I^{2}=0 \%\right.$; Fig. 3$)$.

However, oral propranolol therapy is variable, and we conducted subgroup analysis according to the dose (1.0 or $2.0 \mathrm{mg} / \mathrm{kg}$ ) and the application frequency of oral propranolol therapy (once a day or twice daily). The metaanalysis has shown that there was no significant difference whether the dose of oral propranolol therapy is 1.0 
Table 1. The characteristics of the 6 eligible studies targeting SIH with topical $\beta$-blocker therapy

\begin{tabular}{|c|c|c|c|c|c|c|c|c|c|c|}
\hline \multirow[t]{2}{*}{ Study } & \multirow[t]{2}{*}{ Design } & \multirow[t]{2}{*}{$N$} & \multirow{2}{*}{$\begin{array}{l}\text { Age, } \\
\text { months }\end{array}$} & \multirow[t]{2}{*}{ Regimen and dose } & \multirow[t]{2}{*}{ Frequency } & \multirow[t]{2}{*}{ Diseased sites } & \multirow{2}{*}{$\begin{array}{l}\text { Mean at } \\
\text { initiation, } \\
\text { months }\end{array}$} & \multirow{2}{*}{$\begin{array}{l}\text { Mean } \\
\text { duration, } \\
\text { months }\end{array}$} & \multicolumn{2}{|c|}{ Outcomes } \\
\hline & & & & & & & & & efficacy & $\begin{array}{l}\text { adverse } \\
\text { effects }\end{array}$ \\
\hline \multirow[t]{2}{*}{$\begin{array}{l}\text { Gong et al. } \\
{[10], 2015}\end{array}$} & \multirow[t]{2}{*}{ RCT } & 13 & $2-9$ & $\begin{array}{l}\text { Topical timolol maleate solution, } \\
0.5 \%\end{array}$ & Twice daily & 13 face & n.a. & 6 & 9 & 0 \\
\hline & & 13 & $2-9$ & Propranolol orally, $1.0 \mathrm{mg} / \mathrm{kg}$ & Once a day & 13 face & n.a. & 6 & 9 & 3 \\
\hline \multirow[t]{2}{*}{$\begin{array}{l}\text { Wu et al. } \\
{[8], 2018}\end{array}$} & \multirow[t]{2}{*}{ RCT } & 362 & 5.4 & $\begin{array}{l}\text { Topical timolol maleate } \\
\text { hydrogen, } 0.5 \%\end{array}$ & $\begin{array}{l}\text { Three times } \\
\text { daily }\end{array}$ & $\begin{array}{l}200 \text { head and neck, } \\
84 \text { extremities, } 78 \text { trunk }\end{array}$ & 5.4 & 7.3 & 306 & 0 \\
\hline & & 362 & 6.1 & Propranolol orally, $2.0 \mathrm{mg} / \mathrm{kg}$ & Twice daily & $\begin{array}{l}221 \text { head and neck, } \\
81 \text { extremities, } 60 \text { trunk }\end{array}$ & 6.1 & 6 & 315 & 14 \\
\hline \multirow[t]{2}{*}{$\begin{array}{l}\text { Zaher et al. } \\
{[12], 2013}\end{array}$} & \multirow[t]{2}{*}{ RCT } & 15 & $1-18$ & Topical propranolol ointment, $1 \%$ & Twice daily & $\begin{array}{l}11 \text { head and neck, } 2 \text { trunk, } \\
1 \text { extremities, } 1 \text { buttock }\end{array}$ & n.a. & $5-10$ & 8 & 0 \\
\hline & & 15 & $1-18$ & Propranolol orally, $2.0 \mathrm{mg} / \mathrm{kg}$ & Once a day & $\begin{array}{l}11 \text { head and neck, } 2 \text { trunk, } \\
1 \text { extremities, } 1 \text { buttock }\end{array}$ & n.a. & $3-9$ & 11 & 4 \\
\hline \multirow[t]{2}{*}{$\begin{array}{l}\text { Chan et al. } \\
{[11], 2013}\end{array}$} & \multirow[t]{2}{*}{ RCT } & 19 & $1-3$ & Topical timolol gel, $0.5 \%$ & Twice daily & $\begin{array}{l}9 \text { face, } 3 \text { neck, } 2 \text { torso, } \\
2 \text { thighs, } 2 \text { upper limbs, } 1 \text { back }\end{array}$ & 2.25 & 6 & 9 & 0 \\
\hline & & 22 & $1-3$ & Placebo & Twice daily & $\begin{array}{l}11 \text { face, } 3 \text { neck, } 3 \text { torso, } \\
2 \text { thighs, } 2 \text { upper limbs, } 1 \text { back }\end{array}$ & n.a. & 6 & 2 & 0 \\
\hline \multirow[t]{2}{*}{$\begin{array}{l}\text { Danarti et al. } \\
{[13], 2016}\end{array}$} & \multirow[t]{2}{*}{$\mathrm{RCT}$} & 93 & $1-11$ & Topical timolol maleate gel, $0.5 \%$ & Twice daily & $\begin{array}{l}83 \text { head and neck, } 6 \text { torso, } \\
4 \text { extremities }\end{array}$ & 6 & 6 & 59 & 0 \\
\hline & & 92 & $1-11$ & $\begin{array}{l}\text { Ultrapotent topical corticosteroids, } \\
0.05 \%\end{array}$ & Twice daily & $\begin{array}{l}82 \text { head and neck, } 6 \text { torso, } \\
4 \text { extremities }\end{array}$ & 5.5 & 6 & 28 & 0 \\
\hline \multirow{2}{*}{$\begin{array}{l}\text { Tawfik and } \\
\text { Alsharnoubi } \\
\text { [9], } 2015\end{array}$} & \multirow[t]{2}{*}{ RCT } & 25 & $1-18$ & $\begin{array}{l}\text { Topical timolol maleate solution, } \\
0.5 \%\end{array}$ & Twice daily & $\begin{array}{l}19 \text { face and neck, } 4 \text { torso, } \\
3 \text { vulva, } 4 \text { extremities }\end{array}$ & n.a. & 5 & 18 & 1 \\
\hline & & 25 & $1-18$ & $\begin{array}{l}\text { Pulsed dye and Nd:YAG laser, } \\
585 \mathrm{~nm}\end{array}$ & Once a month & $\begin{array}{l}18 \text { face and neck, } 4 \text { torso, } \\
5 \text { vulva, } 3 \text { extremities }\end{array}$ & n.a. & 6 & 10 & 4 \\
\hline
\end{tabular}

$\mathrm{mg} / \mathrm{kg}(p=0.68)$ or $2.0 \mathrm{mg} / \mathrm{kg}(p=0.22)$, and there was no significant difference whether the application frequency of oral propranolol therapy is once a day ( $p=$ $0.27)$ or twice daily $(p=0.34)$. The dose and application frequency of oral propranolol therapy did not affect the outcome.

Topical $\beta$-Blocker versus Other Interventions (Placebo, Corticosteroids or Pulsed Dye Laser) in Treating SIH. Three studies with $276 \mathrm{SIH}$ patients compared the efficacy of topical $\beta$-blockers with other interventions (placebo, corticosteroids or pulsed dye laser) in treating SIH. In our meta-analysis, the difference in the efficacy was significant between topical $\beta$-blockers and placebo (RR 5.21,95\% CI 1.28-21.21, $p=0.02$ ), topical $\beta$-blockers and corticosteroids (RR 2.08, 95\% CI 1.48-2.94, $p<$ $0.0001)$, topical $\beta$-blockers and pulsed dye laser ( $R R$ $2.14,95 \%$ CI $1.06-4.34, p=0.03)$. There was no heterogeneity and the fixed-effect model was used for analysis $\left(I^{2}=0 \%\right.$; Fig. 4$)$.
Topical $\beta$-Blockers Combined with Another Intervention (Pulsed Dye Laser, Oral Propranolol or Low-Dose ${ }^{90} \mathrm{Sr}$ ${ }^{90} \mathrm{Y}$ ) in Treating $\mathrm{MIH}$. Five studies with $179 \mathrm{MIH}$ patients evaluated the efficacy of topical $\beta$-blockers combined with another intervention in treating $\mathrm{MIH}$. In our meta-analysis, the difference in the efficacy was significant between 2 groups (RR 1.99, 95\% CI 1.10-3.60, $p=0.02, I^{2}=55 \%$; standard mean difference $0.80,95 \%$ CI $0.28-1.31, p=$ $\left.0.002, I^{2}=0 \%\right)$, the random-effect model and fixed-effect model were used for analysis, respectively (Fig. 5).

\section{Outcomes of Adverse Effects}

Topical $\beta$-Blockers versus Oral Propranolol in Treating $\mathrm{SIH}$. Three studies compared the safety of topical $\beta$-blockers with oral propranolol in treating SIH. In our meta-analysis, the difference in the safety was significant between 2 groups (RR 0.05, 95\% CI 0.01-0.39, $p=0.004$ ). There was no heterogeneity, and the fixed-effect model was used for analysis $\left(I^{2}=0 \%\right.$; Fig. 6). 


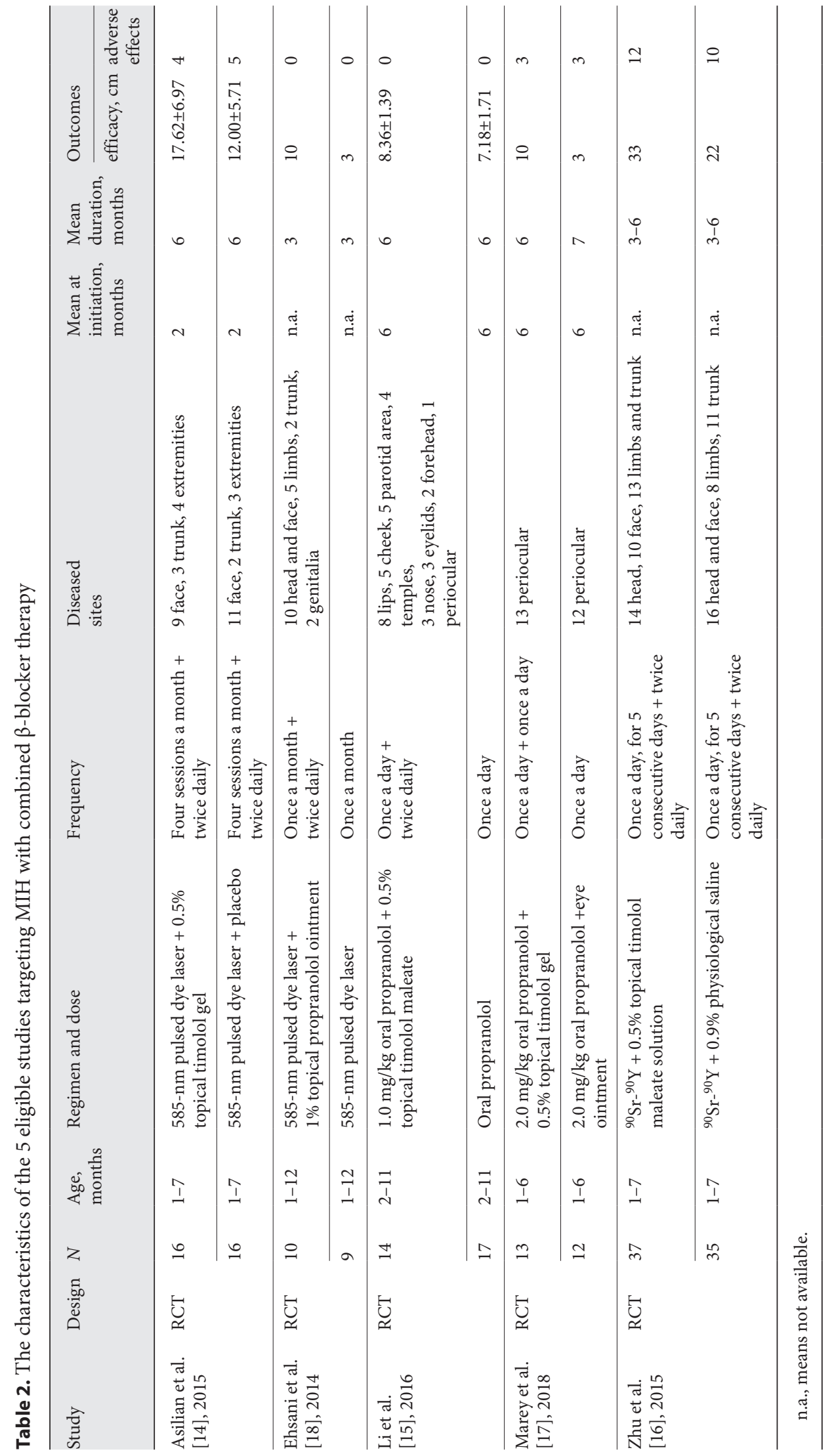




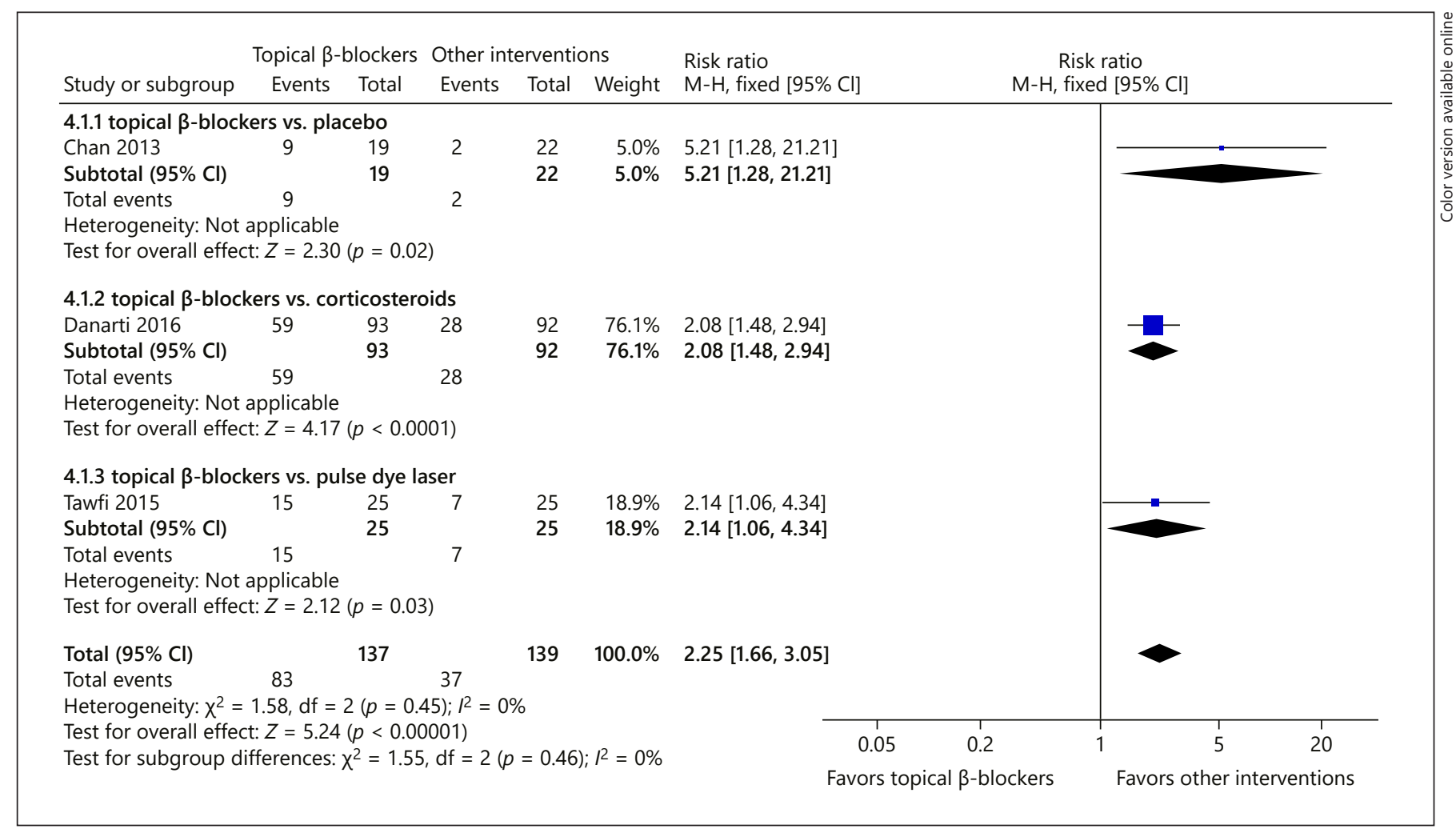

Fig. 4. Forest plot of the efficacy of topical $\beta$-blockers compared with other interventions (placebo, corticosteroids or pulsed dye laser) in treating SIH.

Topical $\beta$-Blockers Combined with Another Intervention (Pulsed Dye Laser, Oral Propranolol or Low-Dose ${ }^{90} \mathrm{Sr}^{9}{ }^{90} \mathrm{Y}$ ) in Treating MIH. Five studies evaluated the safety of topical $\beta$-blockers combined with another intervention in treating MIH. In our meta-analysis, the difference in the safety was not significant between 2 groups (RR $1.01,95 \%$ CI $0.58-1.74, p=0.98)$. There was no heterogeneity, and the fixed-effect model was used for analysis $\left(I^{2}=0 \%\right.$; Fig. 7$)$.

\section{Publication Bias}

Funnel plots in our meta-analysis were shown to assess the publication bias of efficacy and adverse effects (Fig. 8). They were symmetrical and suggested that there was no publication bias for studies included in the analyses.

\section{Discussion}

Rapid proliferation followed by regression is an obvious feature of IH. The rapid growth of IH lesions is usually discovered during $5-8$ weeks and about $80 \%$ of their growth are completed by the age of 3 months. It is widely accepted that the $\beta$-adrenergic receptor plays a crucial role in regulating the growth of $\mathrm{IH}$ [20-22]. Propranolol, as a nonselective $\beta$-blocker, could elicit inhibitory effects through inducing vasoconstriction, angiogenesis inhibition and apoptosis induction [23]. Wu et al. [8] hypothesized that systemic propranolol might mainly target endothelial cells initially, and topical $\beta$-blockers might mainly target pericytes initially. The current first-line treatment for IH is oral propranolol; however, due to the risk of systemic side effects, the use of off-label topical preparations has recently been reported [24]. A systematic review concluded that topical propranolol may be more suitable for SIH at risk of cosmetic sequelae, where the cosmetic or symptomatic impact does not warrant oral propranolol treatment [3]. Even in low-weight preterm infants, topical $\beta$-blockers were effective and devoid of systemic adverse effects [25]. Our meta-analysis indicated that topical $\beta$-blockers were discovered to be as effective as oral propranolol in treating $\mathrm{SIH}$. Besides, a topical $\beta$-blocker combined with another intervention gave rise to better clinical response in the treatment of $\mathrm{MIH}$. 


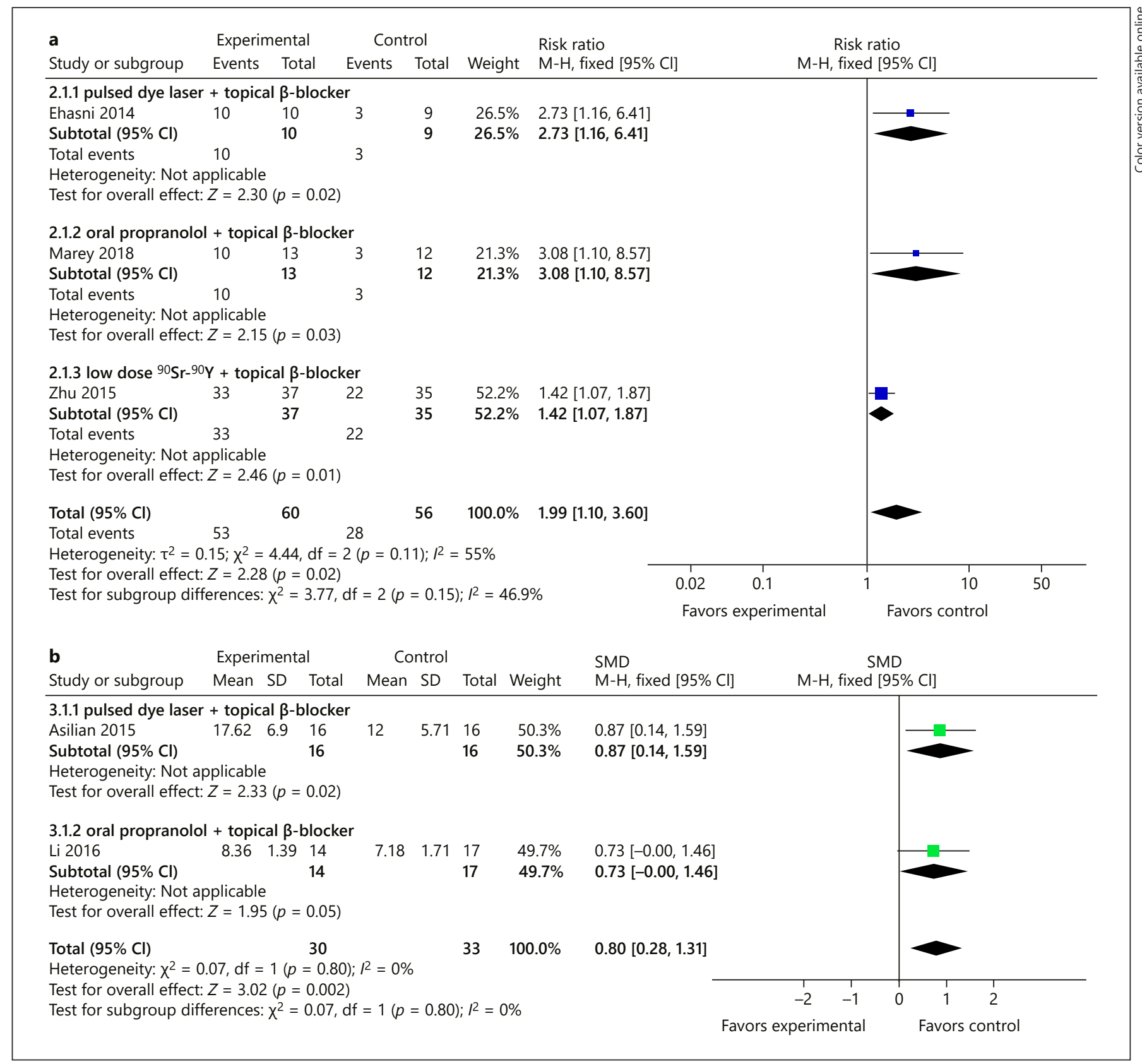

Fig. 5. a, b Forest plot of the efficacy of topical $\beta$-blockers combined with another intervention (pulsed dye laser, oral propranolol or low-dose ${ }^{90} \mathrm{Sr}-{ }^{90} \mathrm{Y}$ ) in treating $\mathrm{MIH}$. SMD, standard mean difference.

Due to the availability of topical timolol, many studies have reported on the use of topical timolol maleate instead of topical propranolol $[26,27]$. Topical timolol maleate is a nonselective, potent adrenergic antagonist $\left(\beta_{1}\right.$ and $\left.\beta_{2}\right)$ that was approved in the USA in 1978 for the treatment of glaucoma and has been safely used as a first-line medication for pediatric glaucoma for more than 30 years [10]. As for SIH, topical medication could achieve local drug distribution and reduce the release of the drug into the blood circulation, so its topical use is safe. Two factors are related to the valid penetration of timolol maleate: the immature skin barrier function of 


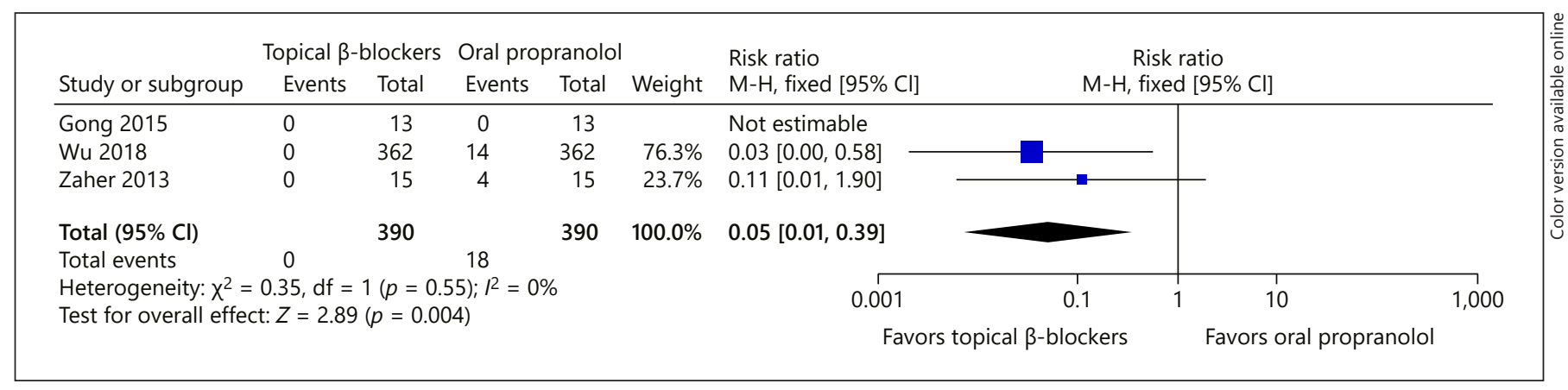

Fig. 6. Forest plot of the safety of topical $\beta$-blockers compared with oral propranolol in treating SIH.

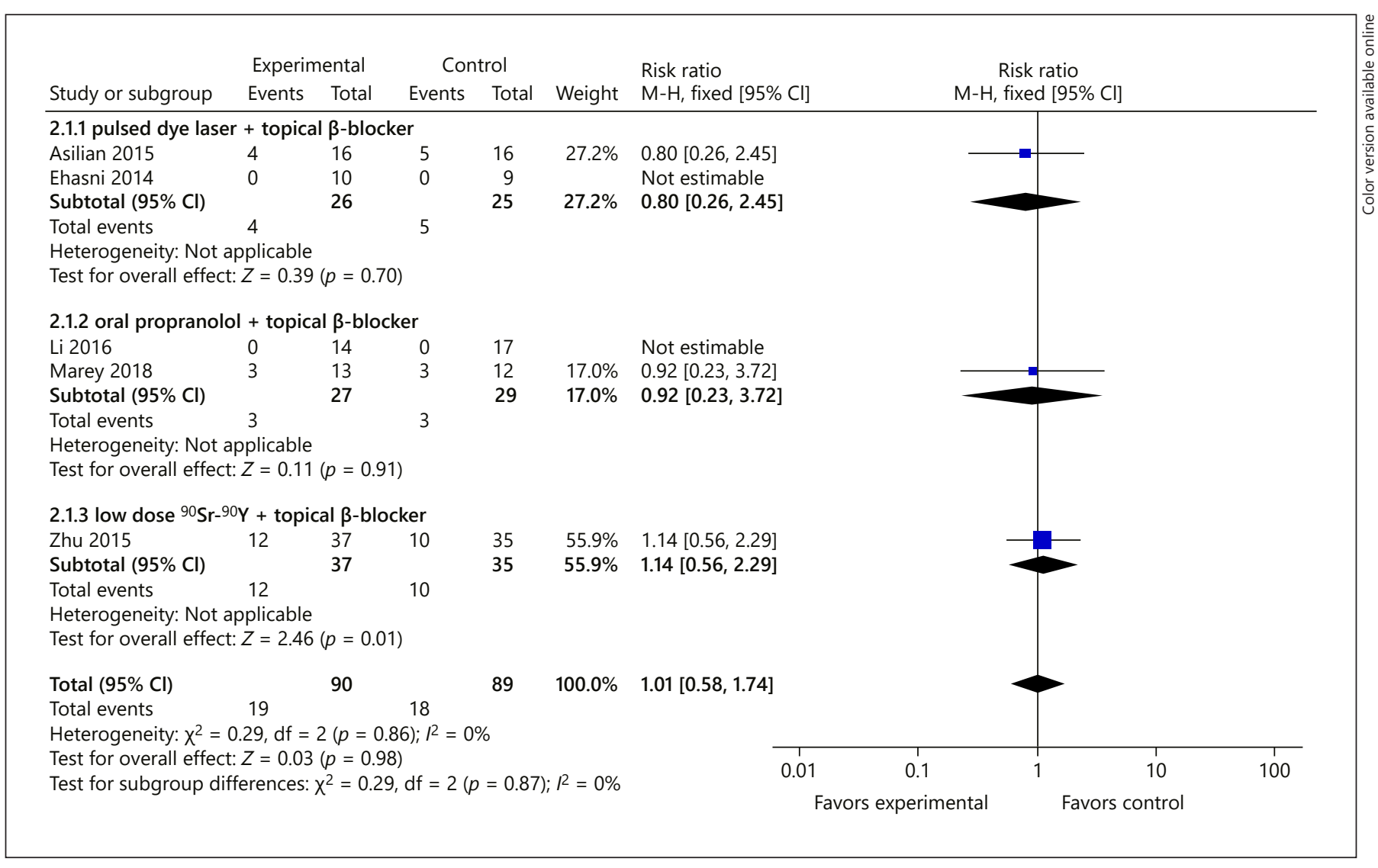

Fig. 7. Forest plot of the safety of topical $\beta$-blockers combined with another intervention (pulsed dye laser, oral propranolol or low-dose ${ }^{90} \mathrm{Sr}^{-}{ }^{90} \mathrm{Y}$ ) in treating $\mathrm{MIH}$.

an infant under the age of 1 year and the lipophilic property of timolol maleate, which improves skin penetration [28]. As for topical timolol, heterogeneous preparations including $0.5 \%$ timolol eyedrop, $0.5 \%$ timolol solution and timolol $0.5 \%$ gel, have been ap- plied for the treatment of SIH $[7,9,11]$. The systemic absorption of timolol gel is considered to be significantly less than that of timolol solution and has been supported in many studies. A randomized placebo-controlled trial suggested that up to 2 drops/day of topical 


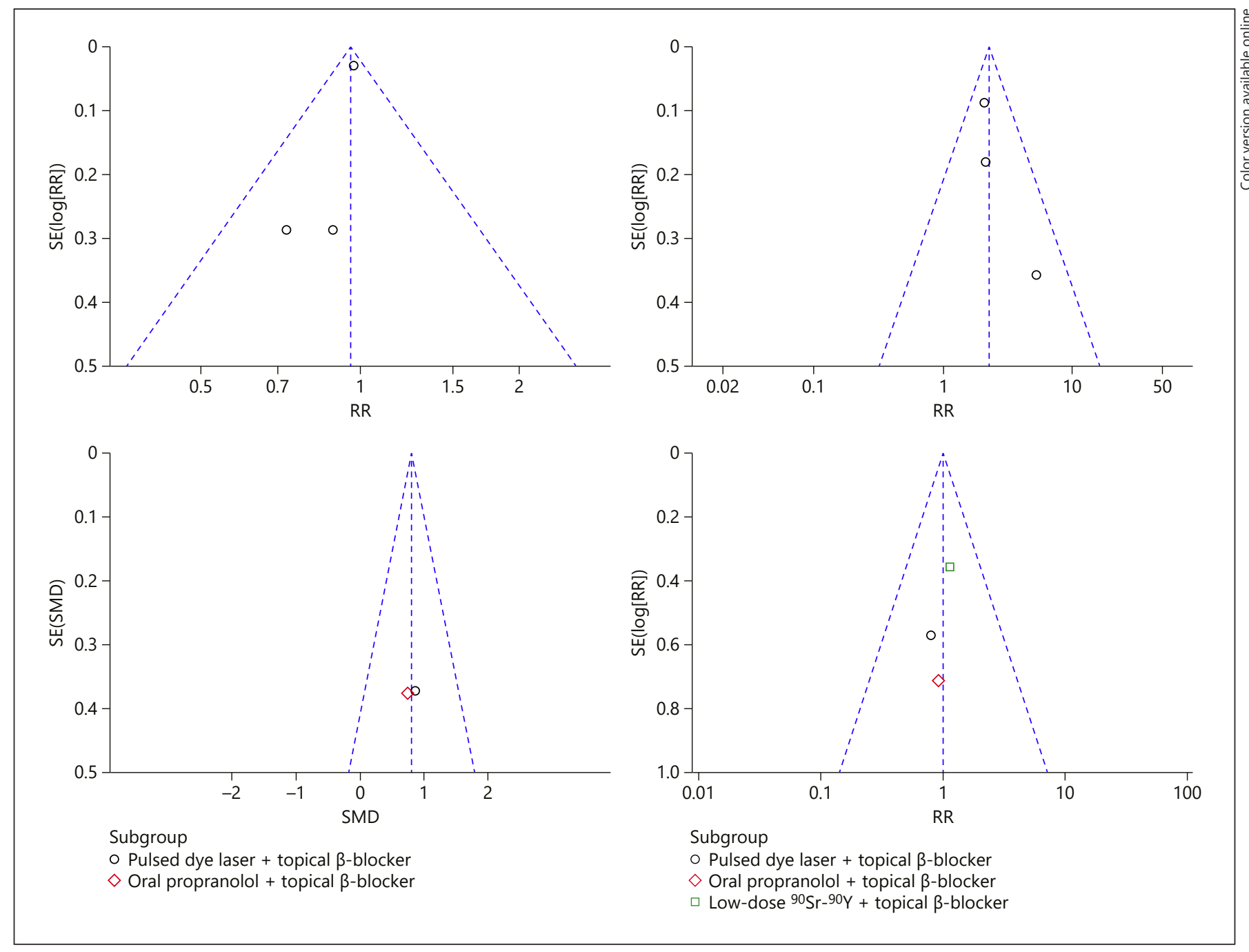

Fig. 8. Funnel plots for publication bias. SE, standard error; RR, relative risk; SMD, standard mean difference.

timolol maleate $0.5 \%$ gel for 24 weeks is a safe and effective therapy for SIH in 5- to 24-week-olds [11].

All 5 studies included in our meta-analysis combined topical $\beta$-blockers with another treatment and demonstrated the additive value of timolol at a concentration of $0.5 \%$. Li et al. [15] found that topical timolol maleate combined with oral propranolol was a well-tolerated and effective treatment, with mild complications, and especially gave rise to a better clinical response in treating MIH than oral propranolol alone. Similarly, Gong et al. [10] discovered that topical timolol maleate together with oral propranolol was safe and effective compared with simple medication. Asilian et al. [14] concluded that topical timolol with pulsed dye laser is accompanied by the

Topical $\beta$-Blockers for Infantile Hemangiomas highest efficacy, cost benefits and a short duration of treatment. For $\mathrm{MIH}$, multiple combined treatments are reported, and the auxiliary role of topical $\beta$-blockers is a topic of future research.

Our meta-analysis showed that topical $\beta$-blockers were associated with fewer adverse events compared with oral propranolol, which is consistent with the study of $\mathrm{Wu}$ et al. [8]. No study included in our meta-analysis mentioned the rebound of $\mathrm{IH}$ in those successfully treated with topical $\beta$-blockers once the medication ceased, and one child in the study of Tawfik and Alsharnoubi [9] showed shortness of breath and insomnia. However, some concerns have been presented regarding the potential systemic absorption and side effects that may arise 
from topical $\beta$-blockers and what specific monitoring requirements are needed while receiving therapy [11]. Some studies reported systemic adverse effects of topical timolol, such as sleep disturbance and symptomatic bradycardia [29]. A case reported a 4-month-old girl with blepharoptosis after treating a thin plaque IH on the upper eyelid with a $0.5 \%$ timolol solution [7]. The safety of topical $\beta$-blockers for ulcerated, mucosal or periorbital $\mathrm{IH}$ also requires further research [30].

Our results may be somewhat limited by small sample sizes and the high number of variables. For IH of different stages, sizes and depths, the dose and course of treatment should be individualized. Because the evaluation criteria of therapeutic effects were different, and the methods of measurement were variable, outcomes were subjective. The age at treatment initiation could have affected therapeutic efficacy; being younger than 6 months at treatment initiation was associated with better outcomes. A more sensitive scoring system and a more comprehensive photographic scale would have improved the study. Larger multicenter randomized controlled trials may provide a unique insight into factors such as site-dependent efficacy as well as dosing, treatment duration, age-groupspecific data and monitoring.

\section{Conclusions}

Topical $\beta$-blocker is a treatment option for $\mathrm{SIH}$, and preliminary evidence suggests that it is effective and safe. Our meta-analysis provided evidence that topical $\beta$-blockers may replace oral propranolol as first-line therapy for SIH. Besides, topical $\beta$-blockers are of additive value in treating $\mathrm{MIH}$.

\section{Key Message}

Topical $\beta$-blockers are effective and safe in treating superficial or mixed infantile hemangiomas.

\section{Acknowledgment}

We wish to thank Tianjin Medical University for providing us with databases.

\section{Statement of Ethics}

This article does not contain any studies with human participants or animals performed by any of the authors.

\section{Disclosure Statement}

The authors have no conflicts of interest to declare.

\section{Funding Sources}

This research received no specific grant from any funding agency, commercial or not-for-profit sectors.

\section{Author Contributions}

X.W. conceptualized and designed the study, drafted the initial manuscript, and interpreted the data; W.F. and X.Z. designed the study and drafted the initial manuscript; Z.L. supervised the analysis; L.D. conceptualized and designed the study, supervised the analysis, interpreted the data and reviewed the manuscript. All authors approved the final paper as submitted and agree to be accountable for all aspects of the work.

\section{References}

1 Baselga Torres E, Bernabéu Wittel J, van Esso Arbolave DL, Febrer Bosch MI, Carrasco Sanz Á, de Lucas Laguna R, et al. [Spanish consensus on infantile haemangioma]. An Pediatr (Barc). 2016 Nov;85(5):256-65.

2 Pandey V, Tiwari P, Sharma SP, Kumar R, Singh OP. Role of intralesional bleomycin and intralesional triamcinolone therapy in residual haemangioma following propranolol. Int J Oral Maxillofac Surg. 2018 Jul;47(7): 908-12.

3 Price A, Rai S, Mcleod RW, Birchall JC, Elhassan HA. Topical propranolol for infantile haemangiomas: a systematic review. J Eur Acad Dermatol Venereol. 2018 Dec;32(12): 2083-9.
4 Hoeger PH, Harper JI, Baselga E, Bonnet D, Boon LM, Ciofi Degli Atti M, et al. Treatment of infantile haemangiomas: recommendations of a European expert group. Eur J Pediatr. $2015 \mathrm{Jul} ; 174(7): 855-65$.

5 Léauté-Labrèze C, Dumas de la Roque E, Hubiche T, Boralevi F, Thambo JB, Taïeb A. Propranolol for severe hemangiomas of infancy. N Engl J Med. 2008 Jun;358(24):2649-51.

6 Léauté-Labrèze C, Hoeger P, MazereeuwHautier J, Guibaud L, Baselga E, Posiunas G, et al. A randomized, controlled trial of oral propranolol in infantile hemangioma. $\mathrm{N}$ Engl J Med. 2015 Feb;372(8):735-46.

7 Guo S, Ni N. Topical treatment for capillary hemangioma of the eyelid using beta-blocker solution. Arch Ophthalmol. 2010 Feb;128(2): 255-6.

8 Wu HW, Wang X, Zhang L, Zheng JW, Liu C, Wang YA. Topical Timolol Vs. Oral Propranolol for the Treatment of Superficial Infantile Hemangiomas. Front Oncol. 2018 Dec;8:605.

9 Tawfik AA, Alsharnoubi J. Topical timolol solution versus laser in treatment of infantile hemangioma: a comparative study. Pediatr Dermatol. 2015 May-Jun;32(3):369-76.

10 Gong H, Xu DP, Li YX, Cheng C, Li G, Wang XK. Evaluation of the efficacy and safety of propranolol, timolol maleate, and the combination of the two, in the treatment of superficial infantile haemangiomas. Br J Oral Maxillofac Surg. 2015 Nov;53(9):836-40. 
11 Chan H, McKay C, Adams S, Wargon O. RCT of timolol maleate gel for superficial infantile hemangiomas in 5- to 24-week-olds. Pediatrics. 2013 Jun;131(6):e1739-47.

12 Zaher H, Rasheed H, Esmat S, Hegazy RA, Gawdat HI, Hegazy RA, et al. Propranolol and infantile hemangiomas: different routes of administration, a randomized clinical trial. Eur J Dermatol. 2013 Sep-Oct;23(5):646-52.

13 Danarti R, Ariwibowo L, Radiono S, Budiyanto A. Topical Timolol Maleate $0.5 \%$ for Infantile Hemangioma: Its Effectiveness Compared to Ultrapotent Topical Corticosteroids - A Single-Center Experience of 278 Cases. Dermatology. 2016;232(5):566-71.

14 Asilian A, Mokhtari F, Kamali AS, AbtahiNaeini B, Nilforoushzadeh MA, Mostafaie S. Pulsed dye laser and topical timolol gel versus pulse dye laser in treatment of infantile hemangioma: A double-blind randomized controlled trial. Adv Biomed Res. 2015 Nov;4(1): 257.

15 Li G, Xu DP, Tong S, Xue L, Sun NN, Wang XK. Oral Propranolol With Topical Timolol Maleate Therapy for Mixed Infantile Hemangiomas in Oral and Maxillofacial Regions. J Craniofac Surg. 2016 Jan;27(1):56-60.

16 Zhu HJ, Liu Q, Deng XL, Guan YX. Efficacy of low-dose 90Sr-90Y therapy combined with topical application of $0.5 \%$ timolol maleate solution for the treatment of superficial infantile hemangiomas. Exp Ther Med. 2015 Sep; 10(3):1013-8
17 Marey HM, Elmazar HF, Mandour SS, Khairy HA. Combined Oral and Topical Beta Blockers for the Treatment of Early Proliferative Superficial Periocular Infantile Capillary Hemangioma. J Pediatr Ophthalmol Strabismus. 2018 Jan;55(1):37-42.

18 Ehsani AH, Noormohammadpoor P, Abdolreza M, Balighi K, Arianian Z, Daklan S. Combination therapy of infantile hemangioma with pulsed dye laser with topical propranolol: a randomized clinical trial. Arch Iran Med. 2014 Oct;17(10):657-60.

19 Achauer BM, Chang CJ, Vander Kam VM. Management of hemangioma of infancy: review of 245 patients. Plast Reconstr Surg. 1997 Apr;99(5):1301-8.

20 Novoa M, Baselga E, Beltran S, Giraldo L, Shahbaz A, Pardo-Hernandez H, et al. Interventions for infantile haemangiomas of the skin: abridged Cochrane systematic review and GRADE assessments. Br J Dermatol. 2019 Mar;180(3):527-33.

21 Menezes MD, McCarter R, Greene EA, Bauman NM. Status of propranolol for treatment of infantile hemangioma and description of a randomized clinical trial. Ann Otol Rhinol Laryngol. 2011 Oct;120(10):686-95.

22 Marqueling AL, Oza V, Frieden IJ, Puttgen KB. Propranolol and infantile hemangiomas four years later: a systematic review. Pediatr Dermatol. 2013 Mar-Apr;30(2):182-91.
23 Novoa M, Baselga E, Beltran S, Giraldo L, Shahbaz A, Pardo-Hernandez H, et al. Interventions for infantile haemangiomas of the skin. Cochrane Database Syst Rev. 2018 Apr; 4:CD006545.

$24 \mathrm{Ni} \mathrm{N}$, Guo S, Langer P. Current concepts in the management of periocular infantile (capillary) hemangioma. Curr Opin Ophthalmol. 2011 Sep;22(5):419-25.

25 Kunzi-Rapp K. Topical propranolol therapy for infantile hemangiomas. Pediatr Dermatol. 2012 Mar-Apr;29(2):154-9.

26 Khan M, Boyce A, Prieto-Merino D, Svensson $\AA$, Wedgeworth E, Flohr C. The Role of Topical Timolol in the Treatment of Infantile Hemangiomas: A Systematic Review and Meta-analysis. Acta Derm Venereol. 2017 Nov; 97(10):1167-71.

27 Zheng L, Li Y. Effect of topical timolol on response rate and adverse events in infantile hemangioma: a meta-analysis. Arch Dermatol Res. 2018 May;310(4):261-9.

28 Stamatas GN, Nikolovski J, Mack MC, Kollias $\mathrm{N}$. Infant skin physiology and development during the first years of life: a review of recent findings based on in vivo studies. Int $J$ Cosmet Sci. 2011 Feb;33(1):17-24.

29 Frommelt P, Juern A, Siegel D, Holland K, Seefeldt M, Yu J, et al. Adverse Events in Young and Preterm Infants Receiving Topical Timolol for Infantile Hemangioma. Pediatr Dermatol. 2016 Jul;33(4):405-14.

30 Boos MD, Castelo-Soccio L. Experience with topical timolol maleate for the treatment of ulcerated infantile hemangiomas (IH). J Am Acad Dermatol. 2016 Mar;74(3):567-70. 